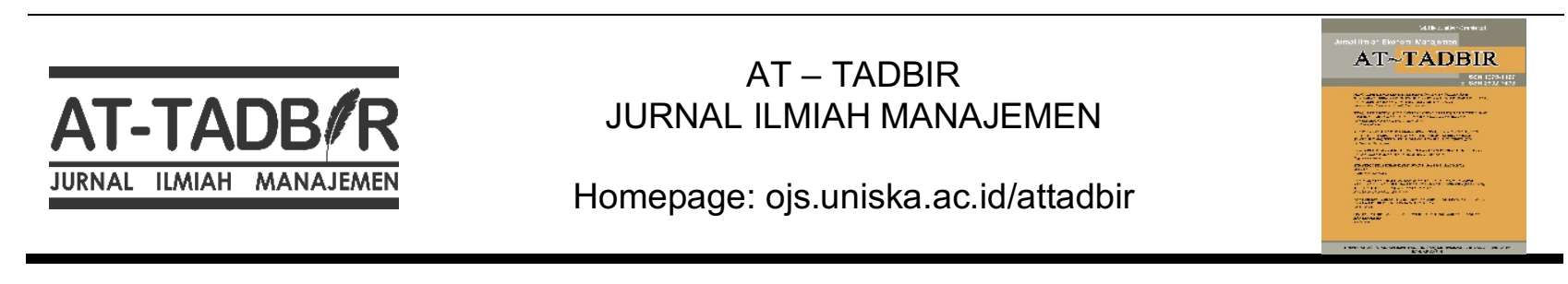

\title{
PENGEMBANGAN RANCANGAN DAN PENGUKURAN KINERJA PERUSAHAAN DENGAN PENDEKATAN BALANCED SCORECARD (Studi Kasus di PT. Natra Raya)
}

\section{Sri Wahyuniawati}

STIE Dahani Dahanai

J1. Cut Nyak Dien No. 09, Kab. Buntok, Kalimantan Tengah

E-mail: wahyunajati@gmail.com

\begin{abstract}
PT. Natra Raya company is licensed by Catterpillar Inc. to produce the Caterpillar heavy equipment. The challenge in seizing market share requires companies to provide competitive prices. The increase in raw material prices, employee wages, transportation costs, charges the company more. The use of Balanced Scorecard on performance measurement helps companies create a comprehensive performance measurement system to measure company performance to be more efficient. This study uses two methods of analysis. The process of making a balanced scorecard design uses quantitative analysis while qualitative used to calculate process, measuring Key performance Indicators weight and performance range. The results of the survey with the balanced scorecard approach show that the performance of PT. Natra Raya is good with an index number of $103.4 \%$ (green code). The balanced scorecard method shows that the performance of PT. Natra Raya cannot only be measured in a limited way. This method can show that there are parts of the indicator that need special attention, namely KPIs with poor performance evaluation results shown in the sub-KPI of employee capability due to the KPI's focus on resources getting a bad score. The sub-KPI, when completing the project, gets a poor performance evaluation result, but outside of the three sub-KPIs, the results of PT. Natra Raya is good and very good.
\end{abstract}

Keywords: Performance Appraisal, Balanced Scorecard, Six Sigma, Key Performance Indicators, Performance Range

\begin{abstract}
Abstrak
PT. Natra Raya perusahaan yang diberikan lisensi oleh Catterpillar Inc untuk memproduksi alat berat merek catterpillar. Tantangan dalam merebut pangsa pasar mengharuskan perusahaan untuk memberikan harga yang kompetitif bahkan cenderung turun dari penawaran harga yang diberikan. Kenaikan harga bahan baku, upah karyawan, biaya transportasi membuat perusahaan mengeluarkan biaya yang lebih besar dalam proses produksinya. Penerapan Balanced Scorecard pada pengukuran kinerja membantu perusahaan membuat sistem pengukuran kinerja yang menyeluruh untuk mengukur kinerja perusahaan agar lebih efisien. Penelitian ini menggunakan dua metode analisis. Proses pembuatan rancangan balanced scorecard menggunakan analisis kuantitatif sedangkan Analisis kualitatif untuk proses penghitungan indeks, penghitungan bobot Key performance Indicators dan performance range. Hasil penelitian dengan pendekatan balanced scorecard menunjukan bahwa kinerja PT. Natra Raya adalah baik dengan angka indeks 103.4\% (kode warna hijau). Metode balanced scorecard menunjukan bahwa kinerja PT. Natra Raya tidak dapat hanya diukur secara terbatas. Metode ini dapat memperlihatkan bahwa ada bagian indikator yang perlu mendapat perhatian khusus yaitu KPI dengan hasil penilaian kinerja tidak baik yang diperlihatkan pada sub KPI kapabilitas karyawan akibat KPI fokus sumber daya mendapat nilai yang buruk. Sub KPI waktu penyelesaian proyek mendapatkan hasil penilaian kinerja tidak baik, namun diluar tiga sub KPI tersebut, hasil penilaian kinerja PT. Natra Raya adalah baik dan sangat baik.
\end{abstract}

Kata kunci: Penilaian Kinerja, Balanced Scorecard, Six Sigma, Key performance Indicators, Performance Range . 


\section{PENDAHULUAN}

Dalam upaya memajukan perekonomian Indonesia secara lebih merata dan efisien, pemerintah terus berupaya menyediakan fasitilas pendukung diantaranya ketersediaan infrastuktur yang dapat membantu memudahkan aliran orang dan logistik. Proses pembangunan infrastuktur memerlukan berbagai peralatan diantaranya adalah alat berat. Pekerjaan konstruksi dalam pembangunan infrastruktur yang memiliki skala besar sangat bergantung pada penggunaan alat berat untuk mempermudah dan mempercepat pekerjaan misalnya untuk memindahkan bahan bangunan juga untuk pengerjaan tanah (earthworking).

Industri alat berat termasuk dalam kategori pasar oligopoli yang berarti bahwa perusahaan penyedia alat berat jumlahnya hanya sedikit di Indonesia. Pappas dan Hirschey (1995) mengkategorikan alat berat sebagai produk yang memiliki permintaan elastis dimana sedikit perubahan terhadap harga akan sangat mempengaruhi jumlah penjualannya.Harga produk ini tergolong mahal untuk memenuhi kebutuhan pasar terutama di bidang konstruksi, pertambangan, kehutanan serta pertanian, perusahaan. Walaupun industri alat berat di Indonesia hanya ada beberapa perusahaan, namun tingkat persaingan dalam merebut pangsa pasar dibidang ini cukup tinggi. Hal ini mengharuskan setiap perusahaan agar terus memiliki kinerja yang baik sehingga dapat menghasilkan produk yang berkualitas serta pelayanan terbaik.

PT. Natra Raya adalah bagian dari perusahaan Catterpillar Inc.yang diberikan lisensi untuk memproduksi alat berat diantaranyai alat berat kehutanan, back hoe loader, Excavator, dozer, dan compactor. PT. Natra Raya telah menghasilkan produk berkualitas tinggi serta memiliki sistem pemasaran yang handal. Tantangan dalam merebut pangsa pasar mengharuskan perusahaan untuk memberikan harga yang kompetitif bahkan cenderung turun dari penawaran harga yang diberikan. Disisi lain kenaikan harga bahan baku, upah karyawan, biaya transportasi membuat perusahaan justru harus mengeluarkan biaya yang lebih besar dalam proses produksinya. Untuk menyikapi hal tersebut PT. Natra Raya berupaya untuk memperbaiki kinerja internalnya agar menjadi perusahaan yang makin efisien melalui program peningkatan kualitas yang disebut dengan Six Sigma. Six Sigma di PT. Natra Raya diterapkan sebagai pelaksanaan dari kebijakan Caterpillar Inc. yang mewajibkan fasilitasnya di seluruh dunia menerapkan Six Sigma sebagai The Way of Life bagi Caterpillar. Menurut Pyzdek (2002), Six Sigma merupakan upaya meningkatkan kinerja perusahaan secara dramatis dan kontinyu untuk mencapai kualitas tingkat dunia. Program peningkatan kualitas Six Sigma dimaksudkan untuk meningkatkan kepuasan konsumen sekaligus meningkatkan kinerja keuangan perusahaan. Dengan program Six Sigma perusahaan berusaha untuk menurunkan biaya-biaya perusahaan (drive down cost), mengurangi kesalahan kerja (reduces defect), memacu pertumbuhan bisnis (fuels growth), meningkatkan kinerja dan servis (improves quality) dan menciptakan efisiensi kerja (creates efficiencies). Dengan demikian biaya yang semula digunakan untuk hal-hal tersebut dapat dikurangi sehingga keuntungan yang diperoleh perusahaan diharapkan akan meningkat.

Penerapan Balanced Scorecard pada pengukuran kinerja diharapkan dapat menjadi alternatif yang membantu perusahaan dalam membuat suatu sistem pengukuran kinerja yang menyeluruh dan mendapatkan hasil pengukuran yang dapat menjadi masukan bagi perusahaan serta dapat 
memberikan umpan balik hasil kinerja perusahaan.

\section{TINJAUAN PUSTAKA}

\subsection{Pengukuran Kinerja}

Kinerja perusahaan sebaiknya dievaluasi setelah periode waktu tertentu. Tujuan dari evaluasi adalah adalah untuk memperoleh informasi penting yang menjadi umpan balik kepada perusahaan. Evaluasi merupakan bagian dari manajemen strategis karena setelah program kerja disetujui dan dilaksanakan, maka pada akhirnya akan dilakukan evaluasi untuk menilai hasil program kerja tersebut. Model evaluasi dapat dilihat pada Gambar 2.1.
A

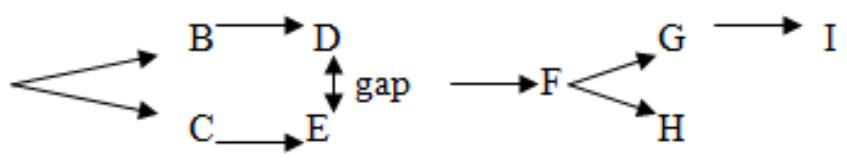

\section{Gambar 2.1. Sebuah Model Evaluasi Kinerja Sumber: Umar, 2002.}

Dari gambar diatas dapat dijelaskan sebagai berikut :

$\mathrm{A}=$ Faktor yang akan dievaluasi

$\mathrm{AB}=$ Apa yang diharapkan dari faktor $\mathrm{A}$

$\mathrm{BD}=$ Rentetan mengenai harapan-harapan atas faktor A, jika ada

$\mathrm{AC}=$ Fakta-fakta mengenai $\mathrm{A}$

$\mathrm{CE}=$ Proses analisis data $\mathrm{AC}$ sehingga menghasilkan nilai $\mathrm{E}$

$\mathrm{DE}=$ Adalah gap, yaitu besar perbedaan antara harapan (D)dan kenyataan (E)

$\mathrm{F}$ = Suatu tolok ukur untuk menilai gap

$\mathrm{G}=$ Adalah hasil evaluasi menggunakan tolok ukur F, bahwa faktor A memang bermasalah

$\mathrm{H}$ = Adalah hasil evaluasi menggunakan tolok ukur F, bahwa faktor A tidak bermasalah

GI = Tindak lanjut hasil evaluasi

Prosedur evaluasi adalah sebagai berikut:

- Menentukan apa yang akan dievaluasi. Umumnya yang dievaluasi adalah hal-hal yang menjadi key success factor- nya.

- Merancang (desain) kegiatan evaluasi. Sebelum evaluasi dilaksanakan, tentukan dahulu desain evaluasinya sehingga dapat diketahui data-data apa saja yang diperlukan dan data mulai dikumpulkan.

- Pengumpulan dan analisis data. Setelah data terkumpul data diolah dan dianalisis dengan menggunakan alat-alat analisis yang sesuai. Selanjutnya dibandingkan antara fakta dan harapan untuk menghasilkan gap.

- Pelaporan hasil evaluasi. Agar hasil evaluasi dapat dimanfaatkan maka hasil evaluasi sebaiknya dilaporkan, baik secara tulisan maupun lisan.

- Tindak lanjut hasil evaluasi. Hasil evaluasi hendaknya dapat digunakan sebagai umpan balik sehingga dapat berguna bagi pihak manajemen, baik ditingkat strategi maupun ditingkat implementasi strategi.

Apa yang dievaluasi, bagaimana mengevaluasinya, siapa yang mengevaluasi dan bagaimana hasil evaluasinya dapat dilakukan secara efektif dan efisien harus dilakukan sesuai prosedur. Pada saat ini pengukuran kinerja tidak lagi hanya menggunakan metode-metode pengukuran tradisional yang berdasarkan standar keuangan semata. Dengan semakin canggihnya teknologi sistem manajemen juga ikut mneyesuaikan diri yaitu dengan munculnya suatu alat pengukuran kinerja yang terintegrasi yaitu balanced scorecard. Balanced scorecard ini merupakan suatu konsep yang diperkenalkan oleh Kaplan dan Norton pada pertengahan tahun 1990. 


\subsection{Balanced Scorecard}

Balanced scorecard dapat menjabarkan strategi ke dalam tindakan dan alat untuk mengukur kinerja organisasi karena balanced scorecard bisa memberikan pemahaman yang cepat dan tepat kepada pihak manajemen dan umpan balik dengan melibatkan perspektif yang penting bagi perusahaan, yaitu perspektif keuangan, perspektif pelanggan, perspektif bisnis internal serta perspektif pembelajaran dan pertumbuhan untuk pencapaian tujuan jangka panjang.

Sebagai kerangka kerja operasionalisasi strategi, penjabaran visi, misi dan strategi ke dalam empat perspektif balanced scorecard dimaksudkan untuk menjawab empat pertanyaan pokok berikut (Yuwono et al, 2002):

a. bagaimana pandangan pelanggan terhadap perusahaan (perspektif pelanggan)

b. proses bisnis internal apa yang harus ditingkatkan/diperbaiki perusahaan (perspektif bisnis internal)

c. apakah perusahaan dapat melakukan perbaikan dan menciptakan nilai secara berkesinambungan (perspektif pembelajaran dan pertumbuhan) d. bagaimana penampilan perusahaan dimata pemegang saham (perspektif keuangan)

Gambar 2.2. menunjukan bahwa balanced scorecard digunakan untuk mengukur kinerja perusahaan berdasarkan empat perspektif yang telah disebutkan di atas. Perspektif keuangan tolok ukurnya adalah hasil tertinggi yang dapat diberikan kepada stakeholder. Hal ini biasanya ditunjukan dengan adanya pemberian target yang harus dicapai. Perspektif pelanggan akan mengukur seberapa fokus perusahaan akan memenuhi kebutuhan pelanggannya. Perspektif bisnis internal lebih menekankan proses yang terjadi dalam operasional seharihari perusahaan. Apa yang menjadi kinerja kunci pendorong proses bisnis internal sehingga dapat mendukung perspektif pelanggan dan keuangan. Terakhir, perspektif pembelajaran dan pertumbuhan yang lebih menekankan pada sumbangsih dari sumberdaya manusia perusahaan. Apa yang dapat mereka berikan dan apa yang dapat diberikan perusahaan kepada mereka yang pada akhirnya akan mendukung ketiga perspektif lainnya.

\begin{tabular}{|l|}
\hline Perspektif Keuangan \\
Mengukur hasil tertinggi yang dapat \\
diberikan kepada pemegang sahamnya \\
\hline Perspektif Bisnis Internal \\
Memfokuskan perhatiannya kepada \\
kinerja kunci proses internal yang \\
mendorong bisnis perusahaan
\end{tabular}

Gambar 2.2. Balanced Scorecard, Sebuah Gambaran Menyeluruh Kinerja Sumber : Yuwono et al, 2002.

\section{Perspektif Pelanggan \\ Fokus terhadap kebutuhan pelanggan, termasuk pangsa pasarnya \\ Perspektif Pembelajaran dan \\ Pertumbuhan \\ Memperhatikan langsung bisnis seluruh sukses mendatang orang-orang dalam organisasi dan infrastruktur.}


yang menggerakan roda proses bisnis internal. Perspektif bisnis internal merupakan proses bisnis internal yang dilakukan oleh karyawan untuk mendorong bisnis perusahaan, baik dalam bentuk pencapaian target produksi, produk yang berkualitas baik, mata rantai operasi maupun pelayanan. Sedangkan perspektif pelanggan dan bagaimana cara mempertahankan atau memperluas pasar, karena pelanggan inilah yang pada akhirnya nanti akan mendorong perspektif keuangan. Perspektif keuangan merupakan hasil nyata dari ketiga perspektif lainnya.

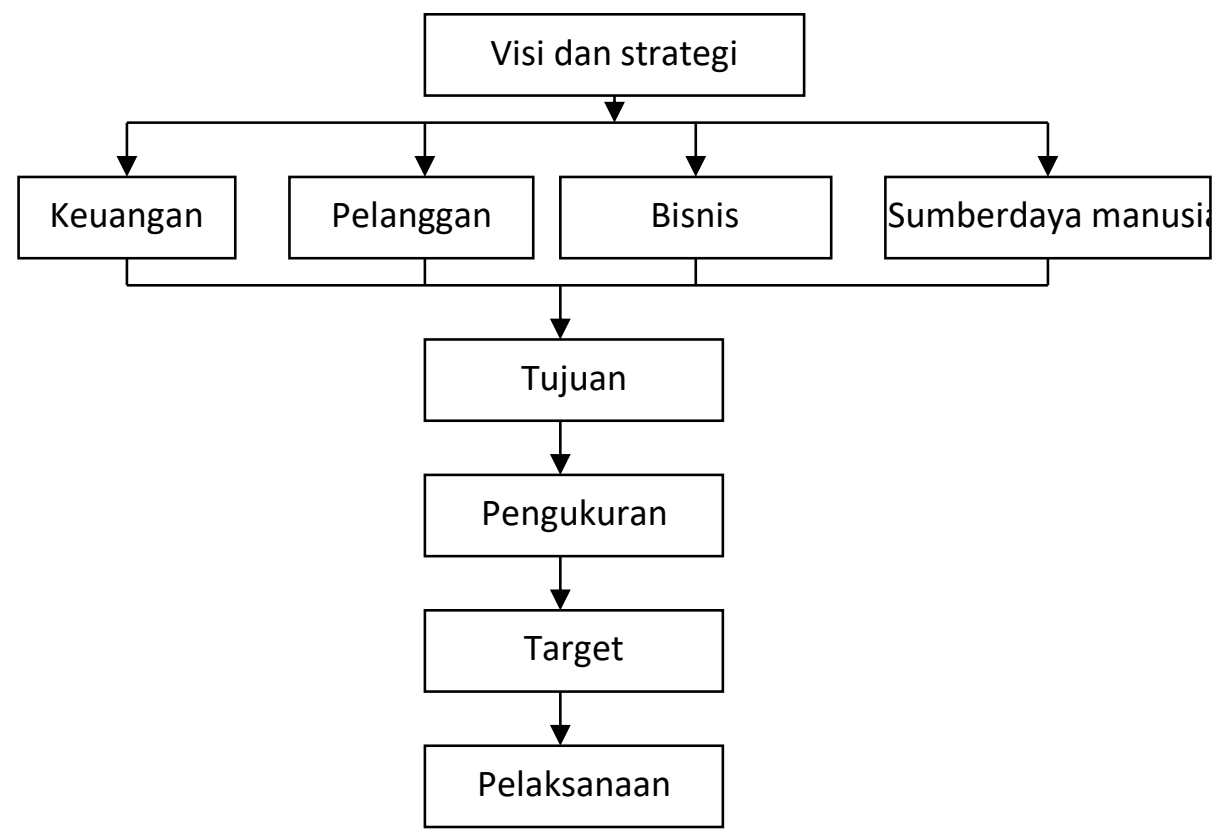

Gambar 2.3. Proses Penjabaran Strategi Sumber : Kaplan \& Norton, 2000

Gambar 2.3. menunjukan bagaimana balanced scorecard mampu menjabarkan strategi hingga pada pelaksanaan program. Tampak pada gambar tersebut visi dan strategi perusahaan dijabarkan pada empat perspektif balanced scorecard. Apa yang merupakan sasaran dan tolok ukur dari masing-masing perspektif yang merupakan turunan dari visi dan strategi perusahaan dijabarkan lebih lanjut. Penjabaran strategi meliputi apa tujuannya, pengukurannya, targetnya dan bagaimana pelaksanaannya sehingga kesemuanya itu menjadi kesatuan dan membawa perusahaan mencapai targetnya.

\section{METODE PENELITIAN}

Jenis Penelitian

Scorecard dan kualitatif pada proses penghitungan indeks, penghitungan bobot Key performance Indicators dan performance range. Penelitian ini menggunakan desain studi kasus sedangkan data yang digunakan adalah data primer dan data sekunder ditambah dengan data-data lain yang ada di luar lingkungan PT. Natra Raya yang dianggap relevan. Jenis dan sumber data secara lengkap dapat dilihat pada Tabel 2.1 . 
Tabel 3.1. Jenis dan Sumber Data

\begin{tabular}{|l|l|}
\hline \multicolumn{1}{|c|}{ Jenis Data } & \multicolumn{1}{|c|}{ Sumber Data } \\
\hline Data primer & \\
\hline Pembobotan empat perpektif balanced scorecard & Kuesioner (Internal) \\
\hline Kepuasan karyawan dan pelaku Six Sigma & Kuesioner (Internal) \\
\hline Data sekunder & \\
\hline Visi dan Misi perusahaan & Internal \\
\hline $\begin{array}{l}\text { company profile } \\
\text { a. Perspektif Keuangan }\end{array}$ & Internal \\
\hline $\begin{array}{l}\text { - laporan cash flow Perspektif Pelanggan } \\
\text { - Data realisasi dan target dari serah terima produk dan } \\
\text { data waktu penyelesaian keluhan pelanggan }\end{array}$ & Internal \\
- Jumlah penjualan alat berat \\
- Indeks penjualan alat berat caterpillar dan \\
$\begin{array}{l}\text { dibandingkan dengan pesaing } \\
\text { - Data keluhan pelanggan }\end{array}$ & Eksternal \\
\hline $\begin{array}{l}\text { c. Perspektif Bisnis Internal } \\
\text { - data realisasi dan target dari serah terima produk dan } \\
\text { data waktu penyelesaian keluhan pelanggan }\end{array}$ & Internal \\
- data biaya produksi & Internal \\
\hline $\begin{array}{l}\text { d. Perspektif pertumbuhan dan pembelajaran } \\
\text { - data performance appraisal rencana kerja individu }\end{array}$ & Internal \\
\hline Penelitian kepustakaan dan informasi pendukung & Internal/Eksternal \\
\hline
\end{tabular}

\section{Metode Analisis Data}

Penelitian ini menggunakan dua metode analisis. Pertama, proses pembuatan rancangan balanced scorecard menggunakan analisis kuantitatif. Analisis kedua menggunakan metode kualitatif yang digunakan untuk mengetahui faktor pendukung dan penghambat bagi perusahaan dalam upaya peningkatan kierja, proses penghitungan indeks, penghitungan bobot Key performance Indicators dan performance range.

\section{HASIL DAN PEMBAHASAN}

\section{Rancangan Balanced Scorecard bagi perusahaan di PT. Natra Raya}

1. Proses Perancangan Balanced Scorecard di PT. Natra Raya
Tahapan dalam melakukan proses perancangan balanced scorecard di PT. Natra Raya adalah mempelajari visi, misi dan strategi perusahaan sehingga bisa diterjemahkan ke dalam rancangan balanced scorecard awal seperti terlihat pada Gambar 4.1. Penetapan Key Success Factor sebagai arahan dalam penetapan sasaran strategis dibuat menyesuaikan dengan tujuan dilaksanakannya program perbaikan di perusahaan

Setelah menentukan rencana strategis, kemudian disusun ukuran strategis yang berguna untuk mengukur sejauh mana sasaran strategis telah dicapai. Ukuranukuran yang telah dihasilkan ini kemudian dipisahkan menjadi ukuran hasil (lag 
indicator) dan ukuran pemacu kinerja (lead indicator).

Tahap selanjutnya adalah menetapkan target dari setiap ukuran, dimana dalam sistem manajemen penyusunan target adalah bagian tak terpisahkan dari scorecard itu sendiri. Dengan adanya target maka komitmen manajemen dan karyawan untuk mencapai apa yang telah direncanakan akan dapat diwujudkan. Balanced scorecard dan target dari setiap ukuran strategis dapat dilihat pada Tabel 4.1.

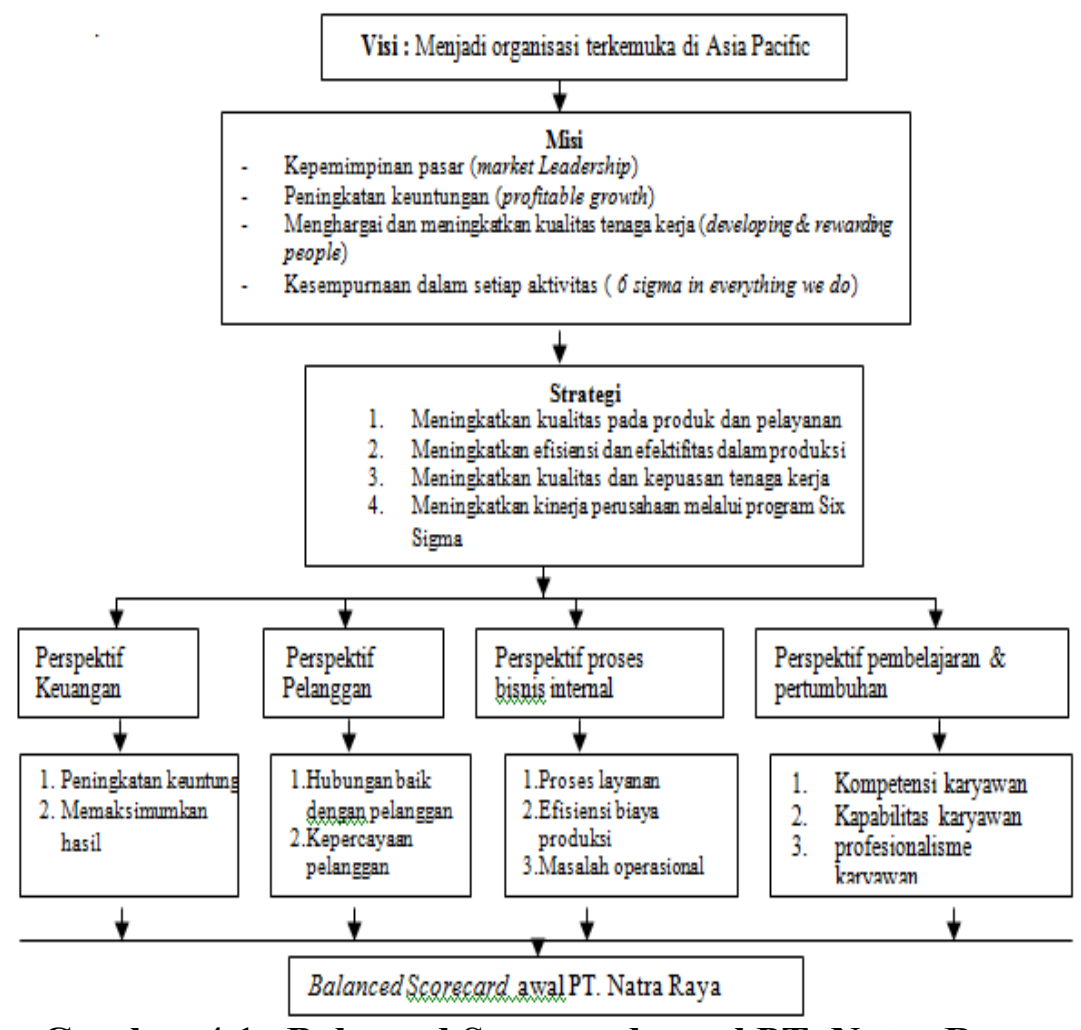

Gambar 4.1. Balanced Scorecard awal PT. Natra Raya

\section{Penetapan Target}

\section{A. Perspektif Keuangan}

Target untuk perspektif keuangan berdasarkan business plan yang dibuat berdasarkan data empiris, data pencapaian tahun sebelumnya, kondisi politik dan keamanan, inflasi dan pertumbuhan ekonomi. Disamping itu penentuan beberapa indikator yang dijadikan target untuk perspektif keuangan memiliki alasan-alasan tertentu misalnya untuk peningkatan keuntungan, ditetapkan sebagai indikator utama karena proses produksi yang dilakukan perusahaan selama ini dianggap masih sangat memungkinkan untuk diturunkan biayanya dan akan berpengaruh besar pada keuntungan yang bisa didapat oleh perusahaan.

Tujuan diberlakukannya program Six Sigma yang kedua adalah penurunan biaya produksi. Penurunan biaya produksi diperoleh dari penghematan yang berhasil dilakukan melalui upaya-upaya perbaikan dalam metode kerja dan efisiensi proses produksi produksi.

\section{B. Perspektif Pelanggan}

Dalam perspektif pelanggan ada beberapa indikator yang ditentukan. Yang pertama adalah hubungan baik dengan pelanggan akan sangat membantu 
meningkatkan kepuasan pelanggan dan mampu mempengaruhi penjualan. Bila konsumen puas, maka kemungkinan besar dia akan membeli lagi. Berdasarkan data-data penjualan yang dimiliki ternyata banyak pengulangan pembelian alat berat yang dilakukan oleh konsumen yang sebelumnya telah menggunakan produk Caterpillar. Oleh karenanya perusahaan memasukkan hubungan baik dengan pelanggan sebagai salah satu KPI. Perspektif pelanggan yang kedua adalah kepercayaan pelanggan yang merupakan alasan bagi pelanggan untuk memutuskan memilih produk Caterpillar daripada produk merek lain, mengingat Caterpillar memiliki harga yang relatif lebih mahal. Dengan adanya kepercayaan dari pelanggan terhadap manfaat dan kualitas alat berat merek Caterpillar yang diproduksi perusahaan, maka mereka bersedia membayar lebih mahal untuk memiliki alat berat yang akan membantu kelancaran usahanya.

\section{Perspektif Proses Bisnis Internal}

Proses bisnis internal merupakan hal penting yang membawa dampak langsung terhadap kinerja karyawan dan kepuasan pelanggan. Proses layanan adalah salah satu indikator yang ditetapkan oleh manajemen. Manajemen beranggapan bahwa dalam memberikan layanan terhadap pelanggan kadangkala terdapat kekurangan dan mengakibatkan pelanggan mengeluh. Pemuasan terhadap kebutuhan konsumen diantaranya dapat dilihat dari penyelesaian pesanan yang tepat waktu serta adanya jaminan layanan purnajual. Masalah opersional juga mendapat perhatian yang besar karena dapat mempengaruhi kinerja perusahaan. Selain itu peningkatan kinerja perusahaan juga dapat dilihat dari efisiensi dalam proses manufakturing yang semakin meningkat setiap tahunnya.

\section{Perspektif Pembelajaran dan Pertumbuhan}

Perspektif pembelajaran dan pertumbuhan merupakan perspektif yang berhubungan dengan sumberdaya manusia. Kompetensi karyawan merupakan aspek yang pertama yang ingin diukur karena dapat menjadi gambaran kemampuan perusahaan menyelesaikan target penyelesaian proyek Six Sigmanya, yang juga berarti mendukung percepatan dalam perbaikan kinerja perusahaan.

Pengembangan karyawan baik untuk mengikuti pelatihan, training, kursus-kursus ataupun berbagai jenis kegiatan pengembangan karyawan lainnya secara rutin telah dilakukan oleh perusahaan. Untuk proyek Six Sigma sendiri, selain pelatihan khusus yang ditujukan bagi Master Black Belt, Black Belt maupun Green Belt, seluruh karyawan telah mendapatkan pelatihan dan memiliki pengetahuan yang memadai mengenai program Six Sigma sehingga seluruh karyawan telah mendapatkan predikat yellow belt. Pengukuran terhadap kompetensi karyawan tetap perlu dilakukan untuk mengetahui sejauh mana hasil dari proses pelatihan selama ini dapat dijalankan oleh karyawan.

Profesionalisme karyawan diukur dengan dengan melihat hasil survey kepuasan karyawan dan tingkat keterlambatan karyawan. Hal ini dilakukan dengan pertimbangan jika karyawan puas terhadap perusahaan maka mereka akan bekerja sepenuh hati dan mengakibatkan kinerja mereka menjadi baik. Hal lain yang termasuk dalam profesionalisme karyawan adalah tingkat ketidakhadiran. Alasan ditetapkannya tingkat ketidakhadiran sebagai 
salah satu aspek yang di ukur karena tingkat ketidakhadiran mencerminkan tanggung jawab dan kedisiplinan karyawan terhadap tugas-tugas pekerjaannya. Tingkat ketidakhadiran yang cukup tinggi akan memberi efek pada efektifitas kinerja karyawan. Kapabilitas karyawan juga mendapat perhatian dari manajemen karena hal ini berkaitan dengan performa kinerja karyawan. Manajemen menginginkan prestasi kinerja perusahaan yang baik dan untuk mendapatkan kinerja perusahaan yang baik maka kinerja karyawan juga harus baik. Untuk menilai kapabilitas karyawan dapat dilakukan dengan cara melihat hasil penilaian kinerja karyawan (performance appraisal) yang setiap tahun dilakukan oleh perusahaan. Selain itu dapat pula dilihat dari jumlah karyawan yang memiliki potensi masuk ke dalam tim inti program peningkatan kualitas Six Sigma.

\section{Peta Strategi}

Peta strategi ini merupakan pandangan menyeluruh melalui keempat perspektif balanced scorecard mengenai strategi dan pelaksanaannya dalam perusahaan. Peta strategi sangat berguna bagi organisasi untuk menjadi suatu organisasi yang berfokus pada strategi, sebagai suatu alat untuk mengkomunikasikan strategi kepada seluruh karyawan dalam bentuk ukuran-ukuran aktifitas operasional. Peta strategi PT. Natra Raya yang disajikan pada gambar 4.2.

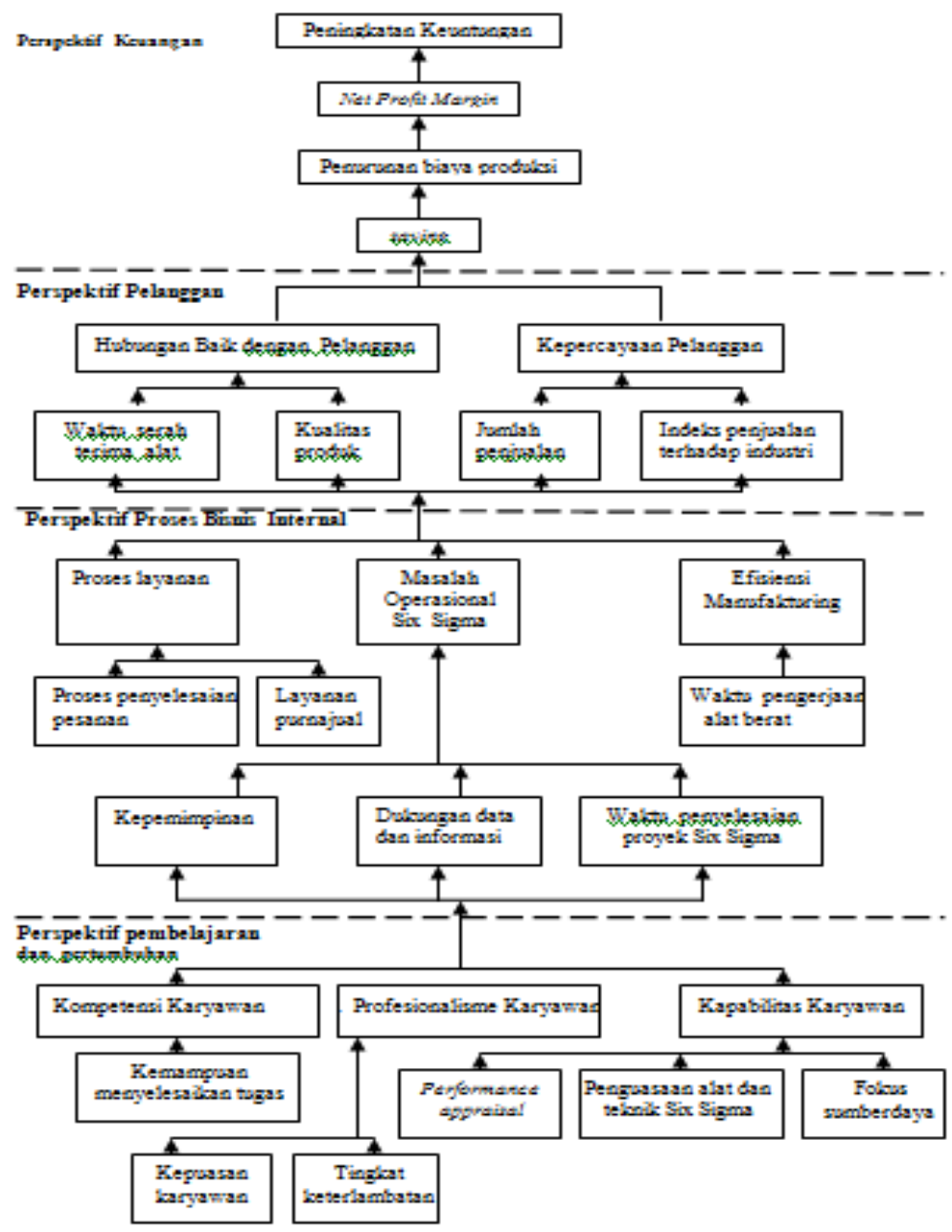

Gambar 4.2. Peta Strategi PT. Natra Raya 
Tabel 4.1. Balanced Scorecard PT. Natra Raya

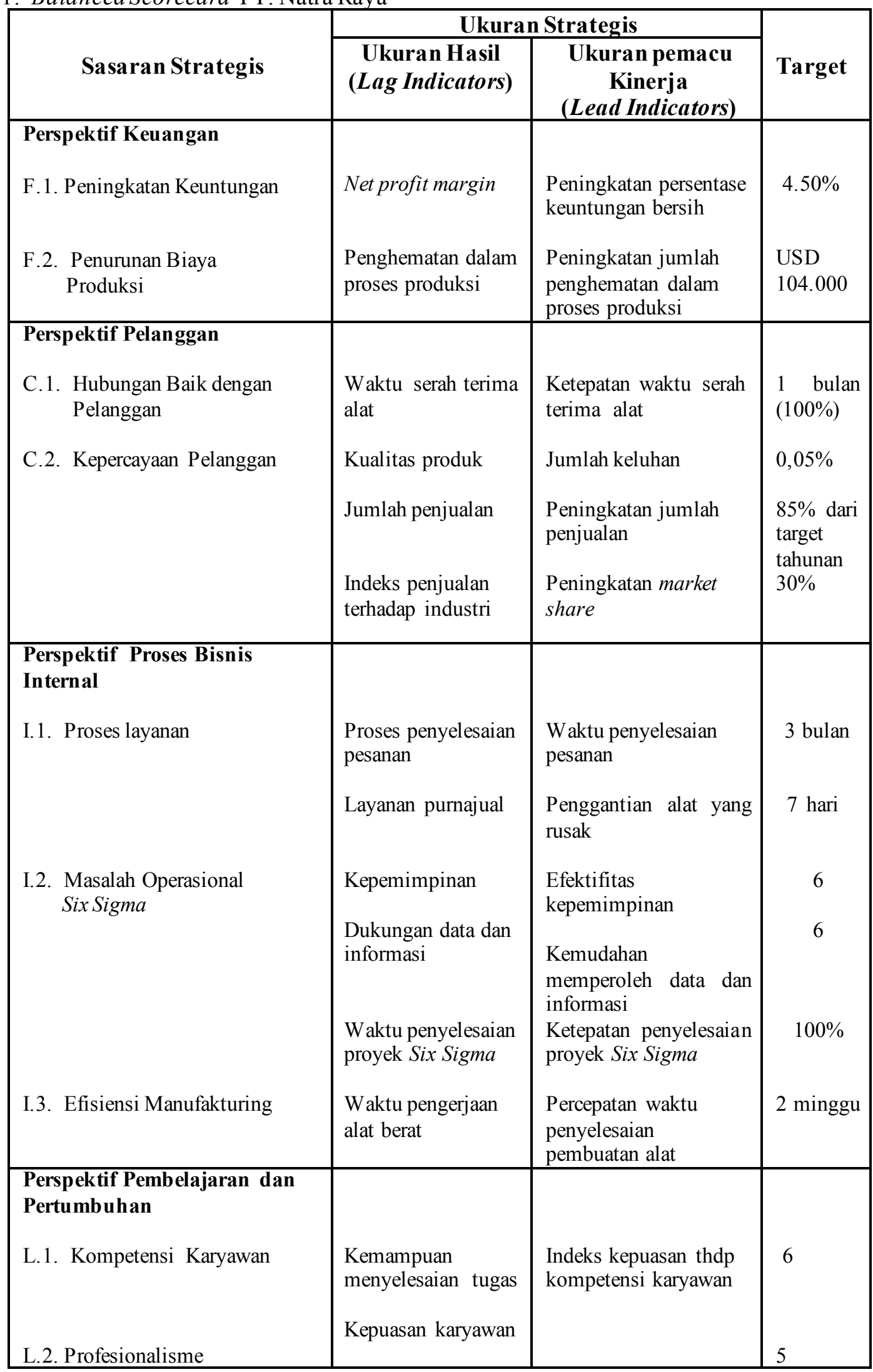




\section{Pembobotan}

Manajemen PT. Natra Raya menentukan bahwa setiap perspektif dan key performance indicator (KPI) mempunyai bobot yang berbeda-beda, sesuai dengan hasil yang ingin dicapai oleh perusahaan. Untuk memperoleh bobot dari setiap perspektif dan KPI, digunakan metode paired comparison yang diisi oleh pihak manajemen dan kemudian dirata-ratakan. Hasilnya dapat dilihat pada tabel 4.2 di bawah.

\section{Hasil Aktual Kinerja}

Target kinerja perusahaan dibandingkan dengan kinerja aktual dapat dilihat pada tabel 4.3 di bawah.

Tabel 4.2. Hasil Pembobotan Rata-Rata Empat PerspektifBalanced Scorecard

\begin{tabular}{|c|c|c|c|}
\hline \multirow{2}{*}{ Perspektif } & \multicolumn{3}{|c|}{ Bobot } \\
\hline & KPI & Grup KPI & Perspektif \\
\hline $\begin{array}{l}\text { Perspektif Keuangan } \\
\text { F.1. Peningkatan Keuntungan } \\
\quad \text { Net profit margin } \\
\text { F.2. Penurunan Biaya Produksi } \\
\quad \text { Penghematan dalam proses produksi }\end{array}$ & $\begin{array}{l}100 \% \\
100 \%\end{array}$ & $\begin{array}{l}50 \% \\
50 \%\end{array}$ & $32 \%$ \\
\hline $\begin{array}{l}\text { Perspektif Pelanggan } \\
\text { C.1. Hubungan Baik dengan Pelanggan } \\
\text { Waktu serah terima alat } \\
\text { Kualitas produk } \\
\text { C.2. Kepercayaan Pelanggan } \\
\text { Jumlah penjualan } \\
\text { Indeks penjualan terhadap industri }\end{array}$ & $\begin{array}{l}35 \% \\
65 \% \\
\\
45 \% \\
55 \%\end{array}$ & $\begin{array}{r}50 \% \\
50 \%\end{array}$ & $19 \%$ \\
\hline $\begin{array}{l}\text { Perspektif Proses Bisnis Internal } \\
\text { I.1. Proses layanan } \\
\text { Proses penyelesaian pesanan } \\
\text { Layanan purnajual } \\
\text { I.2. Masalah Operasional Six Sigma } \\
\text { Kepemimpinan } \\
\text { Dukungan data dan informasi } \\
\text { Waktu penyelesaian proyek Six Sigma } \\
\text { I.3. Efisiensi Manufakturing } \\
\text { Waktu pengerjaan alat berat }\end{array}$ & $\begin{array}{l}50 \% \\
50 \% \\
\\
35 \% \\
35 \% \\
30 \% \\
\\
100 \%\end{array}$ & $\begin{array}{l}40 \% \\
31 \%\end{array}$ & $27 \%$ \\
\hline $\begin{array}{l}\text { Perspektif Pembelajaran dan Pertumbuhan } \\
\text { L.1. Kompetensi Karyawan } \\
\text { Kemampuan menyelesaikan tugas } \\
\text { L.1. Profesionalisme Karyawan } \\
\text { Kepuasan karyawan } \\
\text { Tingkat keterlambatan } \\
\text { L.2. Kapabilitas Karyawan } \\
\text { Performance appraisal } \\
\text { Fokus sumber daya }\end{array}$ & $\begin{array}{l}75 \% \\
25 \%\end{array}$ & $\begin{array}{l}35 \% \\
35 \%\end{array}$ & $22 \%$ \\
\hline
\end{tabular}


Tabel 4.3. Hasil Aktual Kinerja PT. Natra Raya

\begin{tabular}{|c|c|c|c|c|c|}
\hline \multirow[b]{2}{*}{ Sasaran Strategis } & \multicolumn{2}{|c|}{ Ukuran Strategis } & \multirow[b]{2}{*}{ Target } & \multirow[b]{2}{*}{ Aktual } & \multirow[b]{2}{*}{ Rasio } \\
\hline & $\begin{array}{c}\text { Ukuran Hasil } \\
\text { (Lag Indicators) }\end{array}$ & $\begin{array}{c}\text { Ukuran pemacu } \\
\text { Kinerja } \\
\text { (Lead Indicators) } \\
\end{array}$ & & & \\
\hline \multicolumn{6}{|l|}{$\begin{array}{l}\text { Perspektif } \\
\text { Keuangan }\end{array}$} \\
\hline $\begin{array}{c}\text { F.1. Peningkatan } \\
\text { Keuntungan }\end{array}$ & Net profit margin & $\begin{array}{l}\text { Peningkatan } \\
\text { persentase } \\
\text { keuntungan bersih }\end{array}$ & $4.50 \%$ & $5.00 \%$ & $111 \%$ \\
\hline $\begin{array}{l}\text { F.2. Penurunan } \\
\text { Biaya } \\
\text { Produksi }\end{array}$ & $\begin{array}{l}\text { Penghematan } \\
\text { dalam } \\
\text { proses produksi }\end{array}$ & $\begin{array}{l}\text { Peningkatan jumlah } \\
\text { penghematan dalam } \\
\text { proses produksi }\end{array}$ & $\begin{array}{l}\text { USD } \\
104.000\end{array}$ & $\begin{array}{l}\text { USD. } \\
110.000\end{array}$ & $105.76 \%$ \\
\hline \multicolumn{6}{|l|}{$\begin{array}{l}\text { Perspektif } \\
\text { Pelanggan }\end{array}$} \\
\hline \multirow{2}{*}{$\begin{array}{l}\text { C.1. Hubungan } \\
\text { Baik dengan } \\
\text { Pelanggan }\end{array}$} & $\begin{array}{l}\text { Waktu serah } \\
\text { terima alat }\end{array}$ & $\begin{array}{l}\text { Ketepatan waktu } \\
\text { serah terima alat }\end{array}$ & $\begin{array}{l}1 \text { bulan } \\
(100 \%)\end{array}$ & $\begin{array}{l}1 \text { bulan } \\
(100 \%)\end{array}$ & $100 \%$ \\
\hline & Kualitas produk & Jumlah keluhan & $0,05 \%$ & $0.04 \%$ & $125 \%$ \\
\hline \multirow[t]{2}{*}{$\begin{array}{l}\text { C.2. Kepercayaan } \\
\text { Pelanggan }\end{array}$} & Jumlah penjualan & $\begin{array}{l}\text { Peningkatan jumlah } \\
\text { penjualan }\end{array}$ & $\begin{array}{l}85 \% \text { dari } \\
\text { target } \\
\text { tahunan }\end{array}$ & $89 \%$ & $105 \%$ \\
\hline & $\begin{array}{l}\text { Indeks penjualan } \\
\text { terhadap industri }\end{array}$ & $\begin{array}{l}\text { Peningkatan market } \\
\text { share }\end{array}$ & & $35,5 \%$ & $118.3 \%$ \\
\hline \multirow[t]{2}{*}{$\begin{array}{l}\text { Perspektif Proses } \\
\text { Bisnis Internal } \\
\text { I.1. Proses layanan }\end{array}$} & $\begin{array}{l}\text { Proses } \\
\text { penyelesaian } \\
\text { pesanan }\end{array}$ & $\begin{array}{l}\text { Waktu penyelesaian } \\
\text { pesanan }\end{array}$ & 3 bulan & 2 bulan & $150 \%$ \\
\hline & $\begin{array}{l}\text { Layanan } \\
\text { purnajual }\end{array}$ & $\begin{array}{l}\text { Penggantian alat yang } \\
\text { rusak }\end{array}$ & $\begin{array}{c}\text { Max } 7 \\
\text { hari }\end{array}$ & 7 hari & $100 \%$ \\
\hline \multirow{2}{*}{$\begin{array}{l}\text { I.2. Masalah } \\
\text { Operasional } \\
\text { Six Sigma }\end{array}$} & Kepemimpinan & $\begin{array}{l}\text { Efektifitas } \\
\text { kepemimpinan }\end{array}$ & 6 & 5 & $83 \%$ \\
\hline & $\begin{array}{l}\text { Dukungan data } \\
\text { dan informasi }\end{array}$ & $\begin{array}{l}\text { Kemudahan } \\
\text { memperoleh data dan } \\
\text { informasi }\end{array}$ & 6 & 5 & $83 \%$ \\
\hline \multirow[t]{2}{*}{$\begin{array}{l}\text { I.3. Efisiensi } \\
\text { Manufakturing }\end{array}$} & $\begin{array}{l}\text { Waktu } \\
\text { penyelesaian } \\
\text { proyek Six Sigma }\end{array}$ & $\begin{array}{l}\text { Ketepatan } \\
\text { penyelesaian proyek } \\
\text { Six Sigma }\end{array}$ & $\begin{array}{l}4 \text { proyek } \\
\text { selesai }\end{array}$ & $\begin{array}{l}2 \text { proyek } \\
\text { selesai }\end{array}$ & $50 \%$ \\
\hline & $\begin{array}{l}\text { Waktu } \\
\text { pengerjaan alat } \\
\text { berat }\end{array}$ & $\begin{array}{l}\text { Percepatan waktu } \\
\text { penyelesaian } \\
\text { pembuatan alat }\end{array}$ & $\stackrel{2}{2}$ & 10 hari & $140 \%$ \\
\hline
\end{tabular}




\section{Pengukuran Kinerja PT. Natra Raya dengan Rancangan Balanced Scorecard}

Setelah rancangan balanced scorecard selesai dirancang dan hasil aktual dari setiap Key Performance Indicators (KPI) sudah didapatkan, maka kinerja PT. Natra Raya sudah dapat dievaluasi. Evaluasi dari rancangan tersebut secara khusus dapat menggunakan software dari Panorama Business Views. Namun dalam penelitian ini evaluasi kinerja dilakukan dengan bantuan MS Excel untuk memetakan KPI berikut target, kinerja aktual, indeks dan bobot dari setiap perspektif.

Terdapat 4 tingkatan performance range untuk empat perspektif yang dinilai, yaitu:

\begin{tabular}{|c|c|}
\hline Persentase & Kriteria \\
\hline $0.00 \%-37.50 \%$ & $\begin{array}{ll}\text { Sangat } & \text { Tidak } \\
\text { Baik } & \end{array}$ \\
\hline $37.51 \%-75.00 \%$ & Tidak Baik \\
\hline $75.01 \%-112.50 \%$ & Baik \\
\hline $112.51 \%-150 \%$ & Sangat Baik \\
\hline
\end{tabular}

Secara keseluruhan kinerja PT. Natra Raya adalah baik dengan indeks kinerja $104.17 \%$. Terdapat tanda segitiga biru yang berarti ada KPI yang berada pada indeks diatas $112.51 \%$. Kinerja PT. Natra Raya dianggap baik karena didukung oleh penilaian terhadap empat perspektif yang secara umum menunjukan hasil yang baik pula, yang berarti upaya perbaikan kualitas melalui program Six Sigma yang dilakukan perusahaan telah berhasil. Keberhasilan ini menunjukan bahwa perusahaan telah mampu menjabarkan visi dan strategi ke dalam pelaksanaan operasionalnya dan sejalan dengan pernyataan Kaplan dan Norton (2000), yang menyatakan bahwa penjabaran strategi perusahaan yang meliputi apa tujuannya, pengukurannya, targetnya dan bagaimana pelaksanaannya dapat membawa perusahaan mencapai targetnya.

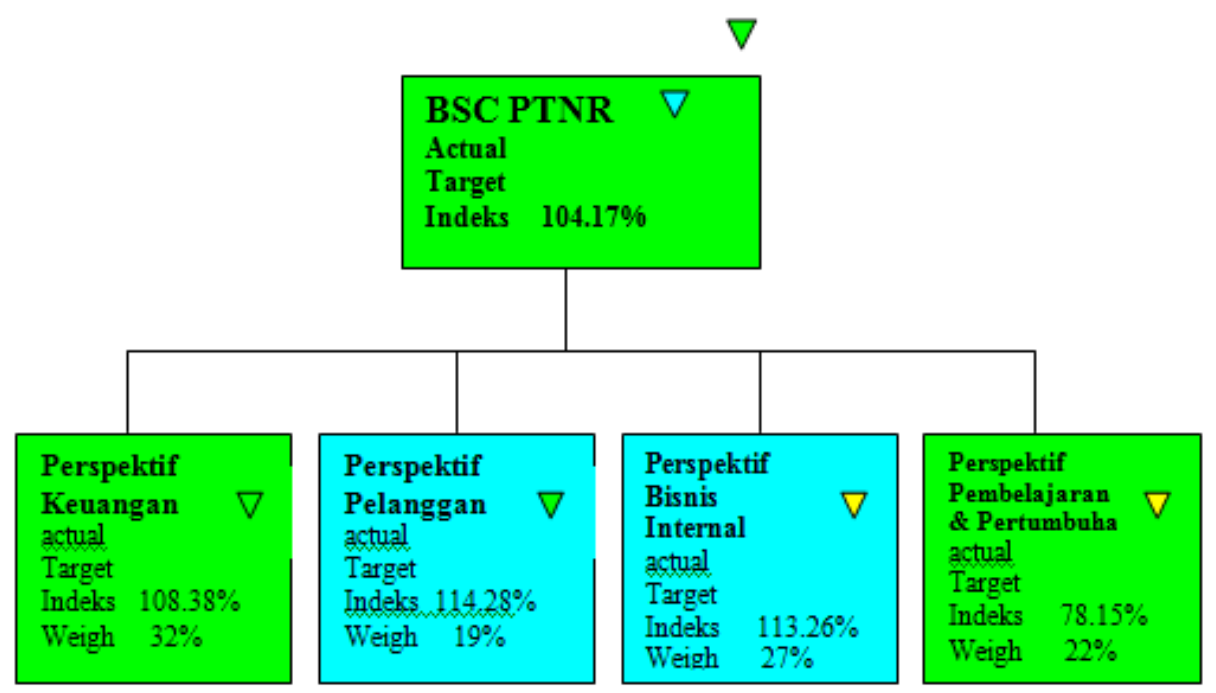

Gambar 4.3. Hasil Penilaian Kinerja PT. Natra Raya dengan Balanced Scorecard 
Tabel 4.4. Hasil kinerja PT. Natra Raya

\begin{tabular}{|l|c|c|c|}
\hline \multicolumn{1}{|c|}{ Sasaran Strategis } & Indeks & Warna & Keterangan \\
\hline Perspektif Keuangan & $108.38 \%$ & Hijau & Baik \\
\hline Perspektif Pelanggan & 114.28 & Biru & Sangat Baik \\
\hline Perspektif Proses Bisnis Internal & $113.26 \%$ & Biru & Sangat Baik \\
\hline Perspektif Pembelajaran dan Pertumbuhan & $78.15 \%$ & Hijau & Baik \\
\hline PT. Natra Raya & $\mathbf{1 0 4 . 1 7 \%}$ & Hijau & Baik \\
\hline
\end{tabular}

\section{Pembahasan}

Balanced scorecard memberikan kerangka kerja, bahasa dan untuk mengkomunikasikan misi dan strategi, dimana scorecard ini juga menggunakan pengukuran yang memberi informasi kepada seluruh pemangku kepentingan serta karyawan agar dapat mengetahui faktor apa saja yang dapat mendorong keberhasilan bagi kinerja perusahaan, Balanced scorecard membantu untuk mengartikulasikan secara lebih detail dan jelas bagaimana hasil kinerja yang diinginkan perusahaan sesuai dengan visi dan misinya. Pihak pimpinan dan seluruh unsur manajemen di PT. Natra Raya diharapkan dapat menyalurkan keahlian, kemampuan dan pengetahuan spesifik sumberdaya manusia agar energi positif terus dirasakan oleh seluruh karyawan dalam perannya mencapai tujuan jangka penjang perusahaan.

Empat perspektif balanced scorecard memberikan keseimbangan antara tujuan jangka pendek dan jangka panjang antara hasil yang diinginkan dengan faktor pendorong tercapainya hasil tersebut, dan diantara ukuran obyektif yang keras dengan ukuran subyektif yang lebih lunak. Sementara keberagaman ukuran pada balanced scorecard jika dilakukan dengan benar mengandung kesatuan tujuan karena semua ukuran diarahkan kepada tercapainya strategi.
Kesulitan-kesulitan yang selama ini ditemui di PT. Natra Raya lebih disebabkan oleh faktor-faktor non keuangan terutama pada teknis pelaksanaan program perbaikan kualitas Six Sigma. Faktor yang berpotensi menghambat pencapaian tujuan perusahaan lebih disebabkan oleh kekurangan jumlah karyawan ahli serta pengaturan dan penjadwalan proyek. Karyawan yang menyatakan puas dengan pekerjaannya juga harus diperhatikan dan mendapatkan pengarahan agar mau berpartisipasi dalam upaya perbaikan.

Penerapan merupakan kelemahan balanced scorecard yang utama. Penerapan balanced scorecard sebagai pengukuran kinerja memakan waktu dan biaya. Semua pihak yang terkait harus meluangkan waktunya untuk mengisi scorecard personel. Selain itu perusahaan harus mempunyai sistem informasi yang mendukung penerapan balanced scorecard . selain itu perusahaan harus memiliki arsip data-data historis yang lengkap dan rapi. Guna data historis ini untuk mengetahui sejauh mana kinerja mengalami peningkatan atau penurunan. Namun untuk PT. Natra Raya sistem informasinya sudah sangat baik dan mendukung hal tersebut.

Memperhatikan hasil penilaian kinerja secara keseluruhan yang menunjukan indeks baik, perusahaan perlu memasukan data pembanding dari perusahaan sejenis agar dapat memiliki gambaran yang lebih 
jelas apakah kinerja perusahaan pada saat ini juga baik jika dibandingkan dengan industri pada umumnya.

Kinerja pada perspektif pelanggan yang sangat baik harus menjadi motivasi untuk terus menjaga dan meningkatkan pelayanan, karena akan banyak faktor yang mampengaruhi pilihan dan tingkat loyalitas pelanggan, sehingga perusahaan harus terus mendengar dan mempelajari pelanggan secara berkesinambungan agar dapat selalu memahami apa yang manjadi keinginan pelanggannya. Perusahaan perlu memahami pula bagaimana karakteristik dari pelanggan potensial dan pelanggan pesaing sehingga dapat mengidentifikasi secara jelas kekuatan dan kelemahan dari produk perusahaan. Secara berkala perusahaan perlu melakukan evaluasi terhadap keinginan pelanggan agar dapat mengetahui aspek-aspek tertentu yang harus diubah atau diperbaiki. Haris (2005) menyatakan bahwa mutu layanan dapat menjadi pembeda antara satu perusahaan dengan perusahaan lain, untuk itu perusahaan perlu terus meningkatkan mutu pelayannya untuk memperkuat tingkat loyalitas pelanggannya. Pelanggan yang loyal akan cenderung memberikan rekomendasi positif dibandingkan dengan pelanggan yang kurang puas atau hanya sekedar puas.

Perspektif proses bisnis internal sangat ditentukan oleh dukungan kepemimpinan yang kuat dalam membimbing, mengawasi dan mengarahkan karyawan. Sistem kepemimpinan harus mampu mendorong pemberdayaan, pembelajaran karyawan dan pengembangan inovasi. Pemimpin dalam perusahaan harus membangun dan mengimplementasikan sistem yang menjamin bahwa nilai-nilai perusahaan dapat dipahami dan dipraktikkan secara konsisten dalam kegiatan operasional. Untuk itu pemimpin harus memberikan arahan secara jelas dan menjamin bahwa semua orang memahami tanggng jawabnya. Keberhasilan perusahaan meraih kemajuan membutuhkan orientasi kedepan dan komitmen yang kuat untuk perbaikan, inovasi, dan disiplin dalam melakukan perubahan yang dibutuhkan. Hal ini memerlukan terciptanya lingkungan yang kondusif untuk pemberdayaan, pembelajaran, inovasi dan disiplin dalam melakukan perubahan yang dibutuhkan.

Perspektif pertumbuhan dan pembelajaran sangat terkait dengan sumberdaya manusia yang ada di perusahaan. Haris (2005) meyatakan bahwa fokus sumberdaya manusia menekankan pada upaya yang diarahkan untuk dapat menciptakan tempat kerja yang dapat menghasilkan kinerja ekselen dan pengembangan pegawai agar mereka dan perusahaan mampu beradaptasi terhadap lingkungan bisnis. Untuk mengatasi permasalahan yang dihadapi oleh perusahaan, perlu dibuat pemetaan terhadap keahlian karyawan, yaitu membandingkan keahlian yang dibutuhkan untuk mewujudkan sasaran strategis dengan keahlian yang dimiliki karyawan saat ini. Dengan mengetahui gap keahlian ini perusahaan dapat membuat keputusan apakah membutuhkan rekruitmen, mempekerjakan sementara atau memberikan pelatihan kepada pegawai. Kegagalan dalam mengidentifikasi karakteristik dan keahlian yang dibutuhkan pegawai potensial akan meningkatkan kecenderungan tidak didapatkannya staf dengan posisi yang benar sesuai kebutuhan.

\section{KESIMPULAN DAN SARAN \\ Kesimpulan}

Perancangan sekaligus penilaian kinerja PT. Natra Raya dengan menggunakan pendekatan balanced scorecard telah 
memberikan gambaran yang menyeluruh terhadap kinerja perusahaan. Perusahaan telah mengidentifikasi Key Performace Indicators melalui empat perspektif pada balanced scorecard sebagai terjemahan dari visi, misi, tujuan dan sasaran perusahan. Perancangan balanced scorecard dimulai dengan menterjemahkan strategi perusahaan ke dalam empat perspektif balanced scorecard yaitu perspektif keuangan, pelanggan, proses bisnis internal serta pembelajaran dan pertumbuhan, berdasarkan tujuan strategis dari masing-masing perspektif. Selain itu dengan memperhatikan key success factor, ukuran-ukuran strategis yang disusun dibedakan menjadi lead dan lag indicators. Langkah terakhir dalam penyusunan rancangan balanced scorecard ini adalah penetapan target dari setiap Key Performance Indicators.

Empat perspektif dalam penelitian ini menghasilkan beberapa variabel pengukur kinerja yaitu:

a. Key Performance Indicators pada Perspektif Keuangan adalah KPI Peningkatan keuntungan dan KPI penurunan biaya produksi.

b. Key Performance Indicators pada Perspektif Pelanggan adalah KPI Hubungan baik dengan pelanggan dan KPI Kepercayaan pelanggan.

c. Key Performance Indicators pada Perspektif Proses Bisnis Internal adalah KPI Proses layanan, KPI Masalah operasional Six Sigma dan KPI Efisiensi manufakturing.

d. Key Performance Indicators pada Perspektif Pembelajaran dan Pertumbuhan adalah KPI Kompetensi karyawan, KPI Profesionalisme karyawan dan KPI Kapabilitas karyawan.
Hasil pengukuran kinerja PT. Natra Raya dengan menggunakan pendekatan balanced scorecard menunjukan bahwa kinerja perusahaan adalah baik dengan angka indeks 104.17\%. Hampir semua indeks kinerja yang diukur memperlihatkan hasil yang baik dan sangat baik dengan nilai yang berkisar antara $75.01 \%$ sampai $150 \%$.

\section{Saran}

Agar kinerja PT. Natra Raya bisa lebih baik lagi , sebaiknya perusahaan melaksanakan beberapa hal di bawah ini:

1. Perusahaan perlu mengetahui kesenjangan antara kondisi aktual karyawan dengan standar keahlian yang dibutuhkan oleh perusahaan agar dapat melaksanan program pelatihan dan pemberian motivasi yang tepat sehingga kualitas dan keahlian suberdaya manusia dapat ditingkatkan

2. Terus berinovasi untuk menghasilkan produk tepat guna sesuai dengan kebutuhan pasar dengan teknologi yang sudah tersedia.

Membuka akses informasi secara lebih mudah dan terbuka bagi pihak yang berkepentingan sehingga data yang diperlukan dapat lebih mudah diakses sehingga penilaian kinerja dan pelaksanaan program Six Sigma perusahaan bisa dilakukan secara lebih cepat dan akurat.

\section{DAFTAR PUSTAKA}

Assauri, S. 1993. Manajemen Produksi. Edisi 4. Lembaga Penerbitan Fakultas Ekonomi Universitas Indonesia. Jakarta. Basu, R. 2004. Six Sigma to Operational Excelence: role of tools and Techniques. International Journal Six Sigma and Competitive Advantage, Vol. 1. No.1, 
pp.44-64.

Gaspersz, V. 2001. balanced Scorecard: Alat Manajemen Kontemporer Untuk Melipat gandakan Kinerja Keuangan Perusahaan. Salemba Empat. Jakarta.

Gaspersz, V. 2001. The Strategy Focused Organization. How Balanced Scorecard Companies Thrive in The New Business Environment. Harvard Business School Press. Boston Massachussets.

Gasperz, V. 2003. Sistem Manajemen

Kinerja Terintegrasi: Balanced

Scorecard dengan Six Sigma untuk Organisasi dan Bisnis dan Pemerintah. PT. Gramedia Pustaka Utama. Jakarta. Kaplan, R.S. dan D.P. Norton. 1992. The Balanced Scorecard Measures That Drive Performance. Harvard Business Review, January-February 1992. p. 7119.

Kotter. J.P. 1997. Leading Change. Menjadi Pionir Perubahan. PT. Gramedia Pustaka Utama. Jakarta.

Ma'arif, M.S. dan Tanjung, H. 2003. Manajemen Operasi. Grasindo. Jakarta.
Pappas, J.L. and Hirschey, M. 1995. Ekonomi Manajerial. Binarupa Aksara. Jakarta.

Russel, R.S. and B.W. Taylor. 1998. Operation Management. Focusing on Quality and Competitiveness. 2nd edition. Prentice-Hall International Inc. New Jersey.

Stevenson, J.W. 1990. Production and Operation Management. Third Edition. Richard D. Irvin, Inc. Boston.

Tenner, A.R. dan de Torro, I.J. 1992. Total Quality Management: Three Steps to Continuous Improvements. Addison Wesley Publishing Company.

Thomson, A., A.J. Strickland. 1996. Strategic Management. Richard Irwin Inc.

Umar, H. 2002. Strategic Management in Action. Gramedia Pustaka Utama. Jakarta.

Wheelen, T.L. and Hunger, J.D. 2001. Manajemen Strategis. Andi Yogyakarta.

Yuwono, S., E. Sukarno, M. Ichsan. 2002. Petunjuk Praktis Penyusunan Balanced Scorecard Menuju Organisasi yang Berfokus Pada Strategi. Gramedia Pustaka Utama. Jakarta 